\title{
Assessment of Indoor Air Quality and Health Impact associated with the use of Different Types of Cooking Stoves amongst Rural Households in Kwara State, Nigeria
}

\author{
1,2*OLAOYE, IJ ; ${ }^{1,3}$ AKINGBADE, AV ; ${ }^{1,4}$ ALATISE, I \\ ${ }^{1}$ Pan African University, Life and Earth Science Institute (including Health and Agriculture), University of Ibadan, Ibadan, Nigeria \\ ${ }^{2}$ Department of Agricultural Economics and Farm Management, university of Ilorin, Kwara State, Nigeria \\ ${ }^{3}$ Nigeria Centre for Disease Control, Plot 80/81, Ebitu Ukiwe Street, Jabi, Abuja, Nigeria \\ ${ }^{4}$ EcoQuest Systematic Limited, Ibadan, Oyo State, Nigeria \\ *Corresponding Author Email: olaoyeibukunjames@gmail.com,Tel: +2347060896827
}

\begin{abstract}
The study focused on assessing the health impact of indoor air pollution and coping strategies adopted among rural households in Kwara state, Nigeria. A three-stage random sampling techniques was used to select 150 household respondents. The data for the study were collected using a well-structured questionnaire and an MSA gas-detector used to monitor the concentration of Carbon-monoxide (CO), Sulphur-dioxide $\left(\mathrm{SO}_{2}\right)$ and Hydrogensulphide $\left(\mathrm{H}_{2} \mathrm{~S}\right)$ pollutants. Descriptive and inferential statistics were employed to analyze the data. However, the result revealed that the mean concentration of $\mathrm{CO}, \mathrm{SO}_{2}$ and $\mathrm{H}_{2} \mathrm{~S}$ in the kitchen during cooking were 77.20, 1.97 and 0.25 parts-per millions (ppm) respectively. The World Health recommends exposure limits of 35ppm for 1hour and 9ppm for 8 hours for $\mathrm{CO}$ concentration in a household. While, the recommended exposure limits of $0.5 \mathrm{ppm}$ and $1.0 \mathrm{ppm}$ for 8 hours, and 5.0ppm and $10.0 \mathrm{ppm}$ for 15 minutes for $\mathrm{SO}_{2}$ and $\mathrm{H}_{2} \mathrm{~S}$ concentrations in a household respectively. Eye irritation, Sneezing and headache were the $1^{\text {st }}, 2^{\text {nd }}$ and $3^{\text {rd }}$ perceived health problems found to be associated with indoor air pollution. Also, the Pearson $\chi^{2}$ result $(15.051,15.454$, and 11.853 with $\mathrm{P}<0.05)$ revealed that cold/catarrh/cough, headache/fever, and body pain ailments respectively have significant association with types of cooking stove used by rural households. Thus, inefficient wood and charcoal stoves influence rural household health negatively and they cope by adopting indigenous management practices.
\end{abstract}

DOI: $\underline{\text { https://dx.doi.org/10.4314/jasem.v25i1.4 }}$

Copyright: Copyright (C) 2021 Olaoye et al. This is an open access article distributed under the Creative Commons Attribution License (CCL), which permits unrestricted use, distribution, and reproduction in any medium, provided the original work is properly cited.

Dates: Received: 02 October 2020; Revised: 26 November 2020; Accepted: 12 December 2020

Keywords: Pollution, concentration, irritation, stove, ailments

Air pollution remains one of the major global environmental challenges of the 21 century most especially in the developing countries. It is the presence of suspended particulate matter (dust, fumes, mist and smoke), gaseous pollutants and odours in the air beyond the level at which it can be tolerated which make it dangerous for human health (Kjellstrom et al. 2006). An estimated 1.5 million deaths were accounted to have occurred annually as a result of household air pollution from solid fuel (World Bank 2007; Legros et al. 2009). It is designated as one of the four most critical global environmental problems in developing countries of the world (Mac 2009). Thus, indoor air pollution is to a large extent caused by household solid fuel used for cooking and heating. Usually, it involves open fires or traditional stoves in conditions of low combustion efficiency and poor ventilation especially among rural communities (Larsen et al. 2008; Bjorn et al. 2008). According to Smith and Mac (2009) high concentration of the primary indoor air pollutants in rural areas was as a result of biomass use. The use of cleaner energy fuels is very low in developing countries compare to developed countries. For example, the use of Liquified Petroleum Gas (LPG) and kerosene in rural areas vary from under 15 percent in Sub-Saharan Africa and South East Asia, 33 percent in the Western Pacific developing region, and closer to 50 percent in Eastern Mediterranean and Latin American countries (International Energy Agency 2014). Thus, biomass remains the dominant energy source in the energy mix of sub-Saharan Africa countries. This account for more than $60 \%$ of the total energy use and nearly 730 million people in SubSaharan Africa rely on the traditional use of solid biomass for cooking (IEA 2014). Also, Chege (1994); Madubansi and Shackleton (2006) identified wood fuel as the main source of energy in rural communities in sub-Saharan Africa and the Indian subcontinent. According to Rehfuess et al. (2006), the main types of traditional fuels used in rural areas are firewood, dung and other agricultural residues, followed by charcoal and coal/lignite. However, deforestation and land degradation are some of the unpleasant challenges

*Corresponding Author Email: olaoyeibukunjames@gmail.com, Tel: +2347060896827 
experienced with the continuous felling of tress for firewood.

The traditional stoves commonly used for burning biomass energy have long been found to emit copious quantities of smoke due to the incomplete combustion of fuels. The smoke emitted from such cooking stoves is made up of particles and gaseous chemicals. And these pollutants have adverse effects on household health. However, the health impact of indoor air pollution in a household depends on many factors. These includes the type of solid fuel and stove, household member exposure to solid fuel smoke (e.g. household member activity patterns, indoor versus outdoor burning of fuels, cooking practices and proximity to stove, and smoke venting factors such as dwelling room size and height, windows and doors, construction material, chimney), and household member age and baseline health status and treatment of illness (Larsen et al. 2008). The smoke emitted from such cooking stoves is made up of particles and gaseous chemicals. The smoke and gases produced by incomplete combustion of biomass causes long-term respiratory health problems and sometimes deaths. Smoke from primitive indoor stoves fueled by wood, coal, crop waste, and dung, kill millions of people worldwide yearly, which mostly affect women and children (IEA and WHO 2010). However, as women primarily responsible for cooking and as children often spend time with their mothers while they engaged in cooking activities. Women and young children are disproportionately directly receiving the harm caused by indoor pollution. For example, the World Health Report (2002) estimates that "acute respiratory infection (ARI) is one of the leading causes of child mortality in the world, accounting for up to $20 \%$ of fatalities among children under five, almost all of them in developing countries (indoor air pollution is thought to cause about one-third of ARI cases)". Also, there is strong scientific evidence linking indoor air pollution (IAP) from the use of solid fuels to pneumonia in young children (Smith et al. 2000; Dherani et al. 2008). This accounted for an estimated $10 \%$ of disease-related deaths in Africa (Bruce et al. 2010) and to chronic obstructive pulmonary diseases such as chronic bronchitis and emphysema in women (American Thoracic Society, 2008). These deaths and DALYs arise mainly from acute lower respiratory infections (ALRI) in young children and chronic obstructive pulmonary disease (COPD) in adults, and to a lesser extent lung cancer and a moderate evidence of increased risk of asthma, cataracts and tuberculosis (Desai et al. 2004; Smith et al. 2004). Moreover, the adverse impacts of IAP from solid fuels in SSA are worse if the numbers of years lost due to ill-health, disability or early death are also considered. If disability adjusted life year (DALY) was used as a measure of overall disease burden, $44 \%$ of all the IAPcased DALYs worldwide occur in SSA (UNDP 2009). These ascertain solid fuels being the second most important environmental cause of disease after contaminated waterborne diseases and the fourth most important cause of overall excess mortality in developing countries after malnutrition, unsafe sex, and waterborne diseases (Bruce et al. 2006). Also, daily discomfort in women that are commonly associated with traditional cooking methods are coughs, headaches, stinging eyes and backaches (WHO 2008). Besides these health impacts, women in rural areas usually spend long hours collecting woodbased biomass - time that would carry higher valueadded to the household if it could be used for childcare, agricultural production, education and other activities. Therefore, the costs incurred in terms of human energy and time required to collect and process such fuel has serious implications on productivity and gender equity. The distances traveled to collect fuelwood vary greatly depending on region and area of the country. For example, distances in a Tanzania case study were up to 10 miles (IEA 2006). This demonstrates that gathering fuelwood can be physically demanding. Also, cooking is responsible for around $5 \%$ of all greenhouse-gas emissions worldwide, which is about 2 billion tonnes of $\mathrm{CO}_{2}$ equivalent emissions per year and three quarters of the emissions is due to inefficient cooking with biomass in developing countries (Stefan 2014). Hence, energy use is an important factor to be considered in achieving both sustainability of environment and human life. This situation is not different also in the Nigeria context being a country in West Africa that is endowed with huge biomass resources. Many rural and urban households still use biomass for cooking particularly charcoal and fuel wood. Oguntoke et al. (2010), reported that more than one-quarter of the residents' in South West Nigeria cook within their dwelling units. Unfortunately, the situation is even worse in the norther part of the country where greater percentage of rural households depend mostly on biomass for cooking and the level of poverty rate in the region is comparatively higher. Also, it is worth highlighting that the prevalent health problems among the households included sneezing, nausea, headache, dizziness, eye irritation, and catarrh associated with cooking with biomass and poor indoor air quality as reported by many past scholars (Oguntoke et al. 2010; Ezzati and Kammen 2001a; Smith et al. 2000; Bruce et al. 2000; WHO 2000; Smith 1993). These health problems are largely consequences of human exposure to high concentration of gaseous pollutants in the air. However, there is dearth of information on indoor air quality and its associated health impact in Nigeria 
particularly in the northern part of the country. Kwara state is one of the states in the north central part of Nigeria; it has large distribution of rural household communities which depend largely on biomass coupled with inefficient stove. Amolegbe and Adewumi (2013), reported in their work on consumption of rural households in Kwara state that about $74.4 \%$ of the energy consumed was from biomass sources. Surprisingly, limited information on the indoor air quality and the health impact of the use of traditional cooking stove in the state. Therefore, the objective of this research work was to assess the indoor air quality and the health impacts associated with use of the type of cooking stoves in rural households in Kwara State, Nigeria.

\section{MATERIAL AND METHODS}

Description of Study Area: The study was carried out in Kwara State, Nigeria. It is in the North Central Geopolitical Zone of the country. It is bounded in the north by Niger state, in the south by Oyo, Osun and Ekiti states and in the east by Kogi state. It also has an international boundary in the west with the Republic of Benin. It is situated between latitudes $11^{\circ} 2^{\prime}$ and $11^{0}$ $45^{\prime} \mathrm{N}$, and longitude $2^{0} 45^{\prime}$ and $6^{0} 4^{\prime} \mathrm{E}$ (KWSPC 2004; NPC 2014). Its location can be considered as midway between the northern and southern parts of Nigeria.

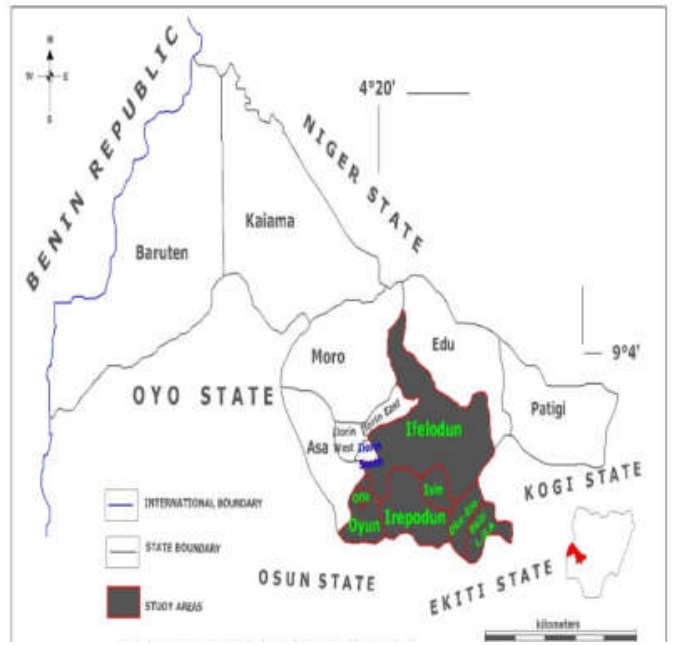

Fig. 1: Map of Kwara State showing all her Local government areas and their headquarters. Source: Olaoye et al., 2020

The seasonal pattern of the state is dual; with dry and wet seasons with the wettest months occurring usually between July and September. Monthly rainfall varies between $50.8 \mathrm{~mm}$ and $241.3 \mathrm{~mm}$ levels with the annual mean rainfall between $745.5 \mathrm{~mm}$ and $1,409.2 \mathrm{~mm}$. Average atmosphere temperature is between $18^{\circ} \mathrm{C}$ and $35^{\circ} \mathrm{C}$. Kwara state has 24 forest reserves covering 5,087.2sq km (NPC 2014). Energy fuel types commonly use among rural households in Kwara State varied mostly from fuelwood, charcoal, kerosene and sometimes in few cases electricity and LPG. The type of stoves mostly used by households in the state includes the traditional tripod stone method, metal charcoal stove and clay lining metal charcoal stove. Figure 1 present the map of the study area.Description of Different Rural Cooking Stoves: Biomass cooking stoves are mainly found in developing countries and represent basic ways of cooking food. Cooking on traditional biomass stoves is mostly related to very low levels of energy efficiency. The most basic type of cooking with biomass is the so-called "three-stone fire", which is made by arranging three stones in such way that it is possible to place a pot for cooking on them. It has been around for thousands of years and is still the most prevalent way of cooking in the world (Cleveland 2004). Thus, over the years, local engineers and fabricators have come up with various improved biomass stoves. These includes the tripod stand metal fuel wood stove, metal charcoal stoves, clay mold charcoal stoves and clay lined metal charcoal stoves in other of their nascent. However, the other non-biomass cooking stoves used by the rural household are the kerosene stove and gas cylinder that uses kerosene and gas respectively which are cleaner fuels. Although, the non-biomass stoves are not common with the rural household in the study area. The plate $2 \mathrm{a}-2 \mathrm{e}$ shows the pictures of various traditional cooking stoves and energy used among rural households.

Collection of Sample: Primary data were used for this study. Two main tools were used for the collection of data for this research work. These include; MSA multi gas sampler and questionnaire. The automated MSA multi gas sampler was used to measure the concentration of $\mathrm{CO}, \mathrm{SO} 2$ and $\mathrm{H} 2 \mathrm{~S}$ pollutant in the kitchen of the selected rural households. The questionnaire was used to collect data on the associated health challenges among the rural households and general observation after the measurement of the indoor air quality. Also, the structured questionnaire was used to collect data on the effects of indoor air pollution and indigenous management/coping practices with IAP respectively. Data were collected within a period of three months $(04 / 03 / 2016-06 / 05 / 2016)$ by the researcher and data on air quality were collected at three (3) time periods per day. The measurement of the rural household indoor air quality was collected for the three-time period in a day during cooking and the control measurement was taking before each of the cooking period. The mean average of the real time 
measurement of the pollutants concentration throughout the cooking period was used.
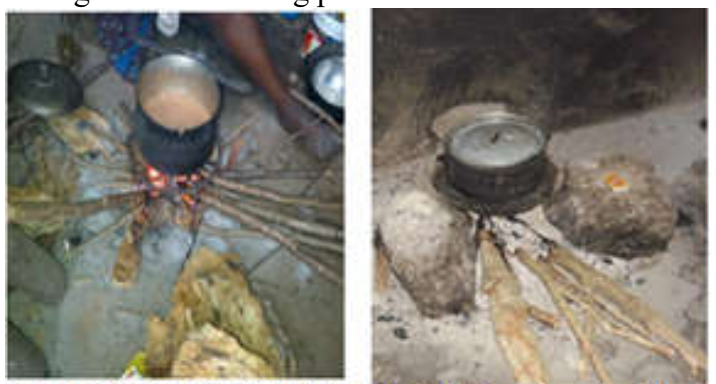

Phate la: Metal Triple Stand Stove Phte 1b: Three Stone Fuel Wood

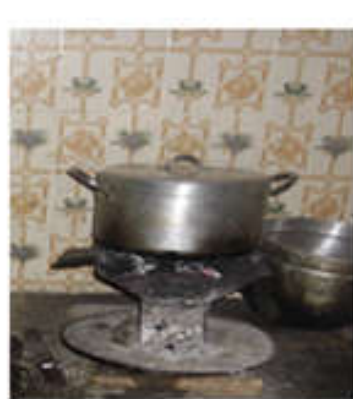

Phte le Metal Charcoal Stove
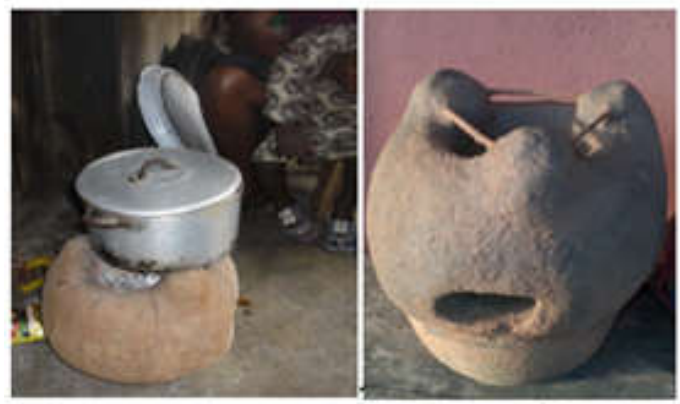

Plate-ld: Mold Clay Charcoal Stove

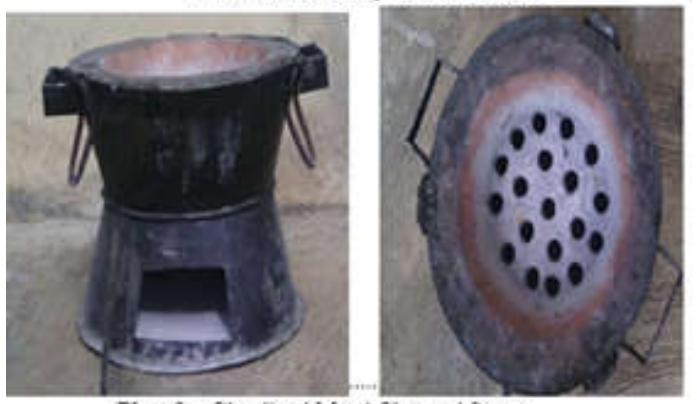

Plate-1e:Clay lined Metal Charcoal Stove'

Source: Plates 1a-le were pictures of different biomass stove during data collection period

Figure 2 present the picture of the MSA gas sampler (apparatus) use for monitoring the air pollutant. Thus, the study involves a cross sectional research design. A multi-stage random sampling technique was used for the selection of the samples used for this study. The first stage involved the random selection of five (5) Local Government Areas in Kwara State. The second stage was the random selection of two (2) communities from each of the local government areas that were selected in the first stage and the third stage involved the random selection of fifteen (15) households in the each of the communities selected at the second stage. Hence, this makes a total of one hundred and fifty (150) respondents.

Determination of various air quality parameters in the sample: The automated MSA gas sampler that was used to monitor the concentration of $\mathrm{CO}, \mathrm{SO}_{2}$, and $\mathrm{H}_{2} \mathrm{~S}$ was measured in parts-per million (ppm). The sampler was used because it measures the real time concentration of the pollutants and requires no further laboratory analysis. Oxygen gas of 20.8ppm was used for the calibration test of the sensor. The green, yellow and red light alarm indicates low, steel and high level of concentration respectively for each of the pollutants. The low, average, and high concentration indicators for $\mathrm{CO}, \mathrm{SO}_{2}$, and $\mathrm{H}_{2} \mathrm{~S}$ are 25:50:100ppm, 2.0:5.0:10.0ppm and 5:10:15ppm respectively. Only the $\mathrm{SO}_{2}$ pollutant was calibrated in a single decimal number while other has no decimal. Before the sensor can accurately monitor the pollutant, it must pass the pump test. To perform the pump test, the sensor is switched on in an area with fairly good air quality distant from any pollution source. The open ended part of the extension tube of the sensor is properly closed to prevent air from entering the sensor in order to perform the pump test. However, the extension tube is opened once the pump test has been passed with the readings on the sampler indicating $0.0 \mathrm{ppm}$ for each of the pollutants. Immediately, the MSA sensor is taken to the kitchen and place on a raised platform at the point where the person doing the cocking was siting.

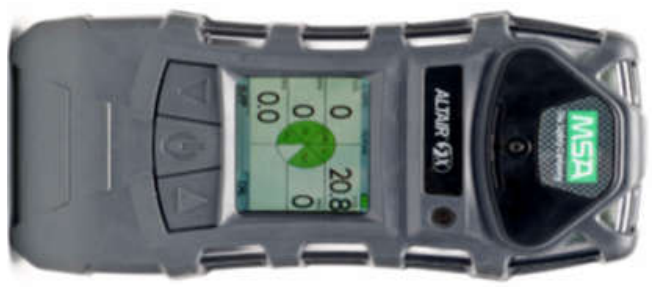

Fig 2: MSA Gas Sampler (sensor)

Data analysis using statistical tool: The data for this study were analyzed using descriptive statistics and inferential statistics. The descriptive statistics includes the mean, mode frequency and percentage. The inferential statistics include ANOVA, and Chi square analysis.

\section{RESULT AND DISCUSSION}


Households Kitchen Indoor Air Quality: The results of the three pollutants that were monitored to assess the air quality of the kitchens among rural households in Kwara south using the MSA gas sampler (sensor) are presented. The data includes the average concentration of $\mathrm{CO}, \mathrm{SO}_{2}$, and $\mathrm{H}_{2} \mathrm{~S}$ during the cooking period in the kitchen of the participating rural households in the study area.

Table 1: Concentration of CO, SO2, and H2S during Cooking Period in the Kitchen of the Rural Households

\begin{tabular}{lllll}
\hline Gaseous Pollutant & Mean $(\mathrm{ppm})$ & Min $(\mathrm{ppm})$ & Max $(\mathrm{ppm})$ & Stand. Deviation \\
\hline Control CO & 0.20 & 0.00 & 6.00 & 0.83 \\
Morning CO & 76.37 & 4.30 & 159.34 & 43.25 \\
Afternoon CO & 80.48 & 5.50 & 167.48 & 46.74 \\
Night CO & 74.74 & 4.00 & 165.11 & 43.29 \\
Control $\mathrm{SO}_{2}$ & 0.083 & 0.00 & 1.05 & 0.18 \\
Morning SO $_{2}$ & 1.98 & 0.30 & 5.00 & 1.07 \\
Afternoon $\mathrm{SO}_{2}$ & 2.07 & 0.30 & 5.10 & 1.16 \\
${\text { Night } \mathrm{SO}_{2}}_{\text {Control } \mathrm{H}_{2} \mathrm{~S}}^{1.85}$ & 0.00 & 0.33 & 5.11 & 1.00 \\
Morning $\mathrm{H}_{2} \mathrm{~S}$ & 0.28 & 0.00 & 0.00 & 0.00 \\
Afternoon $\mathrm{H}_{2} \mathrm{~S}$ & 0.28 & 0.00 & 1.00 & 0.45 \\
Night $\mathrm{H}_{2} \mathrm{~S}$ & 0.31 & 0.00 & 1.00 & 0.46 \\
\hline
\end{tabular}

Source Field Survey Data, 2016; *conversion factor from ppm to $\mathrm{mg} / \mathrm{m}^{3} \mathrm{CO}=1.25, \mathrm{SO}_{2}=2.86$, and $\mathrm{H}_{2} \mathrm{~S}=1.52$

Table 1 shows the concentration of $\mathrm{CO}, \mathrm{SO}_{2}$, and $\mathrm{H}_{2} \mathrm{~S}$ during cooking period in at the kitchen location of rural households. The result revealed that the concentrations of $\mathrm{CO}$ in the kitchens of rural households ranged from 4.00ppm to $167.48 \mathrm{ppm}$ with the overall mean value of $77.20 \mathrm{ppm}$ which is much higher that the permissible limit. Exposure limits for $\mathrm{CO}$ are an average of $35 \mathrm{ppm}$ for one hour, not more than one time per year, or $9 \mathrm{ppm}$ over any eight-hour period (US TSI 2013). Also, WHO 2010, recommended exposures limit of $100 \mathrm{mg} / \mathrm{m}^{3}$ for 15 minutes and $35 \mathrm{ppm}$ for 1 hour (assuming light exercise and that such exposure levels do not occur more often than one per day); $10 \mathrm{ppm}$ for 8 hours (arithmetic mean concentration, light to moderate exercise); and $7 \mathrm{ppm}$ for 24 hours (arithmetic mean concentration, assuming that the exposure occurs when the people are awake and alert but not exercising). The concentration of $\mathrm{SO}_{2}$ in the kitchen of the rural household ranged from $0.30 \mathrm{ppm}$ to $5.11 \mathrm{ppm}$ with the overall mean concentration of $1.97 \mathrm{ppm}$ which was far above the permissible limit. The WHO recommends the exposure limits of $0.5 \mathrm{ppm}$ for 8 hours and $1.0 \mathrm{ppm}$ for 15 minutes for $\mathrm{SO}_{2}$ concentration in a household. Also, the result shows that the concentration of $\mathrm{H}_{2} \mathrm{~S}$ ranged from $0.00 \mathrm{ppm}$ to $1.0 \mathrm{ppm}$ with the mean during morning, afternoon and night cooking were $0.28 \mathrm{ppm}, 0.31 \mathrm{ppm}$ and $0.17 \mathrm{ppm}$ respectively. The recommended exposure limits of $5.0 \mathrm{ppm}$ for 8 hours and 10.0ppm for 15 minutes for $\mathrm{H}_{2} \mathrm{~S}$ concentration in a household. However, the mean concentration of the $\mathrm{H}_{2} \mathrm{~S}$ measure in the kitchen was below the recommended limit. However, the high level of concentration of air pollutants measured agreed with the findings of Traynor et al. (1985) and Knight et al. (1985). Smith (2009) and Mac (2009) attested to high concentration of these parameters and other pollutants in rural areas where biomass energy is the primary source of energy. In order to control for the differences in the stoves type in each of the rural households, the analysis of variance (ANOVA) result was obtained using the stove used by the households as the treatment factor.

Table 2: ANOVA Result of the Measured Pollutant during Cooking at the Kitchen of the Rural Household

\begin{tabular}{llll}
\hline & F-value & Sig & RMK \\
\hline Control CO & 1.169 & 0.328 & Not Significant \\
Morning CO & 51.188 & 0.000 & Significant \\
Afternoon CO & 50.873 & 0.000 & Significant \\
Night $\mathrm{CO}$ & 46.951 & 0.000 & Significant \\
Control $\mathrm{SO}_{2}$ & 1.018 & 0.409 & Not Significant \\
Morning $\mathrm{SO}_{2}$ & 36.076 & 0.000 & Significant \\
Afternoon SO $\mathrm{SO}_{2}$ & 15.114 & 0.000 & Significant \\
${\text { Night } \mathrm{SO}_{2}}_{\text {Control } \mathrm{H}_{2} \mathrm{~S}}^{46.951}$ & 0.000 & Significant \\
Morning $\mathrm{H}_{2} \mathrm{~S}$ & 13.575 & 0.000 & Significant \\
Afternoon $\mathrm{H}_{2} \mathrm{~S}$ & 11.695 & 0.000 & Significant \\
Night $\mathrm{H}_{2} \mathrm{~S}$ & 4.321 & 0.001 & Significant \\
\hline \multicolumn{4}{c}{ Source: Field survey data 2016.}
\end{tabular}

Table 2 show the ANOVA result which explained the variation among the level of pollutant measured in the kitchens location of the participating rural households. The result revealed that there is no significant difference in the concentration of $\mathrm{CO}, \mathrm{SO}_{2}$, and $\mathrm{H}_{2} \mathrm{~S}$ (P.value $>0.05$ ) of air quality when there is no cooking activity. While, there is a significant difference in the concentration of $\mathrm{CO}, \mathrm{SO}_{2}$, and $\mathrm{H}_{2} \mathrm{~S}(\mathrm{Pv}<0.05)$ of air quality during cooking whether breakfast, lunch or dinner. This difference might be as result of the differences in kitchen location, stove type, fuel type and ventilation within the kitchen environment. According to Smith et al. (2004) and Balakrishnan et al. (2002), factors responsible for the difference in concentrations of indoor air pollutants are; the type of biomass burnt, stove type, burning intensity, kitchen area, ventilation rate, spatial distribution of pollutants, and duration of monitoring. 
Kitchen or Cooking Point Location: Table 3 shows the categories of points of cooking or the location of kitchen house commonly used by the respondent which varies from indoor to outdoor. The result revealed that $64.67 \%$ of the rural women cook indoor while $35.33 \%$ of the rural women do their cooking outdoor. This result was contrary to the findings of Oguntoke et al. 2010 which revealed that $75.3 \%$ and $24.7 \%$ do their cooking outdoor and indoor respectively. However, this wide variation might be as a result of variation in culture and economic characteristics of the respondents.

Table 3: Location of points of cooking/Kitchen area of the Respondents

\begin{tabular}{lll}
\hline Cooking Location & Frequency & Percentage \\
\hline Indoor & 97 & 64.67 \\
Outdoor & 53 & 35.33 \\
\hline Total & 150 & 100.00 \\
\hline \multicolumn{3}{c}{ Source: Field Survey data, } \\
\hline
\end{tabular}

Average Hour Spent Indoor per day among Rural Household Women: Table 4 shows the result of the hours spent indoor by the rural women. And the result shows that many $(52.00 \%)$ of the rural women spent between $6-9$ hours indoor while, the $24.66 \%$ of the respondents spent between 10 to 12 hours indoor. Also, few $(2.00 \%)$ of the rural households spent above 18 hours indoor and $6.67 \%$ spent between 16 to 18 hours indoor. The result further revealed that the average hours spent among the rural household women selected for this study was 10.56 hours. This indicated that majority of the rural women less than an average of 12 hours indoor. This implies that they were at risk of any adverse effects of long period of exposure to indoor air pollution and couple with the fact that they were believed to do the cooking for each of their respective households. Hence, they were open to pollution from inefficient cooking stove and impure fuel given their frequent visit to the kitchen and proximity to stove while cooking.

Table 4: Average Hour Spent Indoor per day among Rural Household Women

\begin{tabular}{lll}
\hline Hour spent indoor/day & Frequency & Percentage \\
\hline $6-9$ & 78 & 52.00 \\
$10-12$ & 37 & 24.66 \\
$13-15$ & 22 & 14.67 \\
$16-18$ & 10 & 6.67 \\
$>18$ & 3 & 2.00 \\
\hline Total & 150 & 100.00 \\
\hline \multicolumn{3}{r}{ Source: Field Survey data, 2016}
\end{tabular}

Health Impact of Indoor Air Pollution: Here, the result of the perceived effects of indoor air pollution and the prevailing health conditions of the participating rural households are represented in Table 5. A three point Likert scale was used to determine the degree of occurrence of health issues.

Table 5: Effect of Indoor Air Pollution among Rural Households in Kwara South

\begin{tabular}{llllll}
\hline Health problem & Frequently & Seldom & No at all & Mean & Rank \\
\hline Eye irritation & $84(56.00)$ & $37(24.67)$ & $29(19.33)$ & 2.37 & $1^{\text {st }}$ \\
Dry throat & $47(31.33)$ & $33(22.00)$ & $70(46.67)$ & 1.85 & $7^{\text {th }}$ \\
Head ache & $54(36.00)$ & $47(31.33)$ & $49(32.67)$ & 2.03 & $3^{\text {rd }}$ \\
Skin irritation & $26(17.33)$ & $51(38.00)$ & $73(48.67)$ & 1.69 & $9^{\text {th }}$ \\
Sneezing & $69(46.00)$ & $39(26.00)$ & $42(28.00)$ & 2.18 & $2^{\text {nd }}$ \\
Shortness of breath & $16(10.67)$ & $23(15.33)$ & $110(73.33)$ & 1.36 & $10^{\text {th }}$ \\
Cough & $49(34.00)$ & $40(26.67)$ & $61(40.67)$ & 1.92 & $5^{\text {th }}$ \\
Dizziness & $39(26.00)$ & $49(32.67)$ & $62(41.33)$ & 1.85 & $7^{\text {th }}$ \\
Nausea & $37(24.67)$ & $63(42.00)$ & $50(33.33)$ & 1.91 & $6^{\text {th }}$ \\
Catarrh & $44(29.33)$ & $64(42.67)$ & $42(28.00)$ & 2.01 & $4^{\text {th }}$ \\
\hline \multicolumn{5}{c}{ Source: Field Survey data, 2016; *Figure in parentheses were percentage }
\end{tabular}

Table 5 shows the effects of indoor air pollution among rural households in Kwara South. The mean score generated using the 3 point likert type scale was used to rank the perceived health problems associated with indoor air pollution as a result of inefficient cooking methods. Thus, the result revealed that eye irritation, sneezing and head ache were the $1^{\text {st }}, 2^{\text {nd }}$ and $3^{\text {rd }}$ perceived health problems associated with indoor air pollution of the pollutants from the inefficient cooking methods by the rural household with the mean score of 2.37, 2.18 and 2.03 respectively. While, skin irritation and shortness of breath were the least perceived health problem by the respondents with the mean score of 1.69 and 1.36 , and this were ranked $9^{\text {th }}$ and $10^{\text {th }}$ respectively. This result is in tandem with the report of Oguntoke et al. (2010) that investigated indoor air pollution and identified eye irritation, head ache, catarrh and nausea as the associated health risks among rural dwellers in Odeda Area, South western Nigeria.

Associated Health Problems Treated recently by the member(s) of the households: In assessing the health problems recently treated by members of the households selected for this study, a cross tabulation analysis of the identified ailments against the type of stoves use by the household was done. This reveal the likely association between the various type of stoves and the common ailments recently treated among the households selected. Table 6 shows the result of the 
cross tabulation and the respective Pearson Chi square $\left(\chi^{2)}\right)$. While, Figure 3 shows the percentage distribution of the responses for each identified health problem in association with their cooking stove types.

Table 6: Frequency distributions of the cross tabulation of the ailments recently treated by members of each of the households

\begin{tabular}{|c|c|c|c|c|c|c|c|c|c|c|c|c|c|c|}
\hline \multirow{3}{*}{$\begin{array}{l}\text { STOVE } \\
\text { TYPE }\end{array}$} & \multicolumn{14}{|c|}{ Ailments recently treated by members of each of the households } \\
\hline & \multicolumn{2}{|c|}{ Malaria } & \multicolumn{2}{|c|}{ Typhoid } & \multicolumn{2}{|c|}{ Body Pain } & \multicolumn{2}{|c|}{$\begin{array}{l}\text { Stomach } \\
\text { Ache }\end{array}$} & \multicolumn{2}{|c|}{$\begin{array}{l}\text { Yellow } \\
\text { Fever }\end{array}$} & \multicolumn{2}{|c|}{$\begin{array}{l}\text { Head } \\
\text { Ache/Fever }\end{array}$} & \multicolumn{2}{|c|}{$\begin{array}{l}\text { Cold/Catarrh/ } \\
\text { Cough }\end{array}$} \\
\hline & Yes & No & Yes & NO & Yes & No & Yes & No & Yes & No & Yes & No & Yes & No \\
\hline $\begin{array}{l}\text { Fuel wood } \\
\text { Stove } \\
\text { Metal } \\
\text { Charcoal }\end{array}$ & 44 & 34 & 13 & 65 & 47 & 31 & 19 & 59 & 3 & 75 & 75 & 3 & 62 & 16 \\
\hline $\begin{array}{l}\text { Stove } \\
\text { Clay } \\
\text { Charcoal }\end{array}$ & 25 & 6 & 5 & 26 & 20 & 11 & 4 & 27 & 2 & 29 & 26 & 5 & 22 & 9 \\
\hline $\begin{array}{l}\text { Stove } \\
\text { Clay Lining } \\
\text { Metal } \\
\text { Charcoal }\end{array}$ & 6 & 4 & 1 & 9 & 5 & 5 & 1 & 9 & 0 & 10 & 7 & 3 & 4 & 6 \\
\hline $\begin{array}{l}\text { Stove } \\
\text { Kerosene }\end{array}$ & 13 & 1 & 5 & 9 & 9 & 5 & 5 & 9 & 3 & 11 & 8 & 6 & 11 & 3 \\
\hline Stove & 12 & 3 & 3 & 12 & 12 & 3 & 4 & 11 & 0 & 15 & 6 & 9 & 8 & 7 \\
\hline Gas Cylinder & 1 & 1 & 0 & 2 & 0 & 2 & 1 & 1 & 0 & 2 & 0 & 2 & 0 & 2 \\
\hline $\begin{array}{l}\text { Total } \\
\text { Pearson Chi }\end{array}$ & 101 & 49 & 27 & 123 & 93 & 57 & 34 & 116 & 8 & 142 & 122 & 28 & 107 & 43 \\
\hline Square & & $2.487^{*}$ & & 4.057 & & $853^{*}$ & & 5.078 & & 9.123 & & $15.454 *$ & & $15.051 *$ \\
\hline Sig. & & 0.029 & & 0.541 & & 0.037 & & 0.406 & & 0.104 & & 0.009 & & 0.010 \\
\hline
\end{tabular}

This result indicated an association with the challenges associated with air pollutant of incomplete combustion. The Pearson $\chi^{2}$ result $(15.051,15.454$, 12.48 , and 11.853) revealed the incomplete combustion of fuel was associated with illness like; cold/catarrh/cough, head ache/fever, malaria and body pain ailments $(\mathrm{P} .<0.05)$. But, there were no significant association with other identified health ailments (i.e., stomach ache, typhoid and yellow fever). Although, based on previous research work, it has been established that there is association between indoor air pollution (IAP) and breathing (lung) related health problem. Thus, the significant association in the cases of cold/catarrh/cough and head ache/fever with the cooking stove types might be due to respondent exposure to IAP. Also, numerous studies have found associations between IAP and acute lower respiratory infection (Smith et al. 2000; Ezzati and Kammen 2001a; 2001b), chronic obstructive pulmonary disease (Bruce et al. 2000; WHO 2002) and lung cancer in the case of coal smoke (Mumford 1987; Smith 1993). However, the following graph (Figure 3a-g) shows the percentage distributions of the cross tabulation of the ailments recently treated by members of each of the households given the type of cooking stoves.

Characteristics of Stove and Fuel type, their Prices and the CO Emission Level in Rural Household Kitchen: Table 7 presents the stove and fuel types with their respective prices and $\mathrm{CO}$ emissions. Both the tripod stone stove and the metal triple stand stove uses fuel wood energy. The tripod stone stove is more technically efficient than the metal tree stand stove since it is known to consume less fuel quantity $(4.30 \mathrm{~kg}$ $<4.50 \mathrm{~kg}$ ) and better air quality. The ordinary clay charcoal stove is also technically efficient that both the metal and the clay lined metal charcoal stove since it consumed less fuel with better air quality performance. Although, the ordinary clay and the clay lined metal charcoal stoves both show higher superiority and improvement over the ordinary metal charcoal stove. Considering the use of the cleaner fuel options (kerosene and gas), the gas also shows a great superiority in terms of fuel quantity and air quality $(5.44 \mathrm{ppm}<23.14 \mathrm{ppm}$ concentration of $\mathrm{CO})$. Also, the use of the ordinary cay charcoal stove is a little better than the use of kerosene stove in a household since its $22.56 \mathrm{ppm}<23.14 \mathrm{ppm}$ concentration of $\mathrm{CO}$. However, the initial price of stove and fuel price remain major factors that the rural household considered in the adoption of a particular stove design and not it health and environmental factor (Masera et al. 2000; Schlag and Zuzarte 2008; Puzzolo 2013). Majority of the households that uses fuel wood collected the wood freely in the bush. But it is the prevailing market price that was used in calculating the cost of the fuel wood been consumed by the household per meal preparation. The higher prices of the initial cost of the gas cylinder and the gas discourage the adoption of this stove. Lastly, both the ordinary clay and the clay lined metal charcoal stove are best efficient in terms of the fuel cost implication. However, the result of the fuel wood stove having a higher $\mathrm{CO}$ emission level than the charcoal based stove is found to be contrary to a 
number of past studies. For example, Eldred and Satoshi reported an averaged $\mathrm{CO} \pm \mathrm{SD}$ concentration for every kitchen with wood was $44 \pm 21$, and $77 \pm 49$ for charcoal stoves in their study.
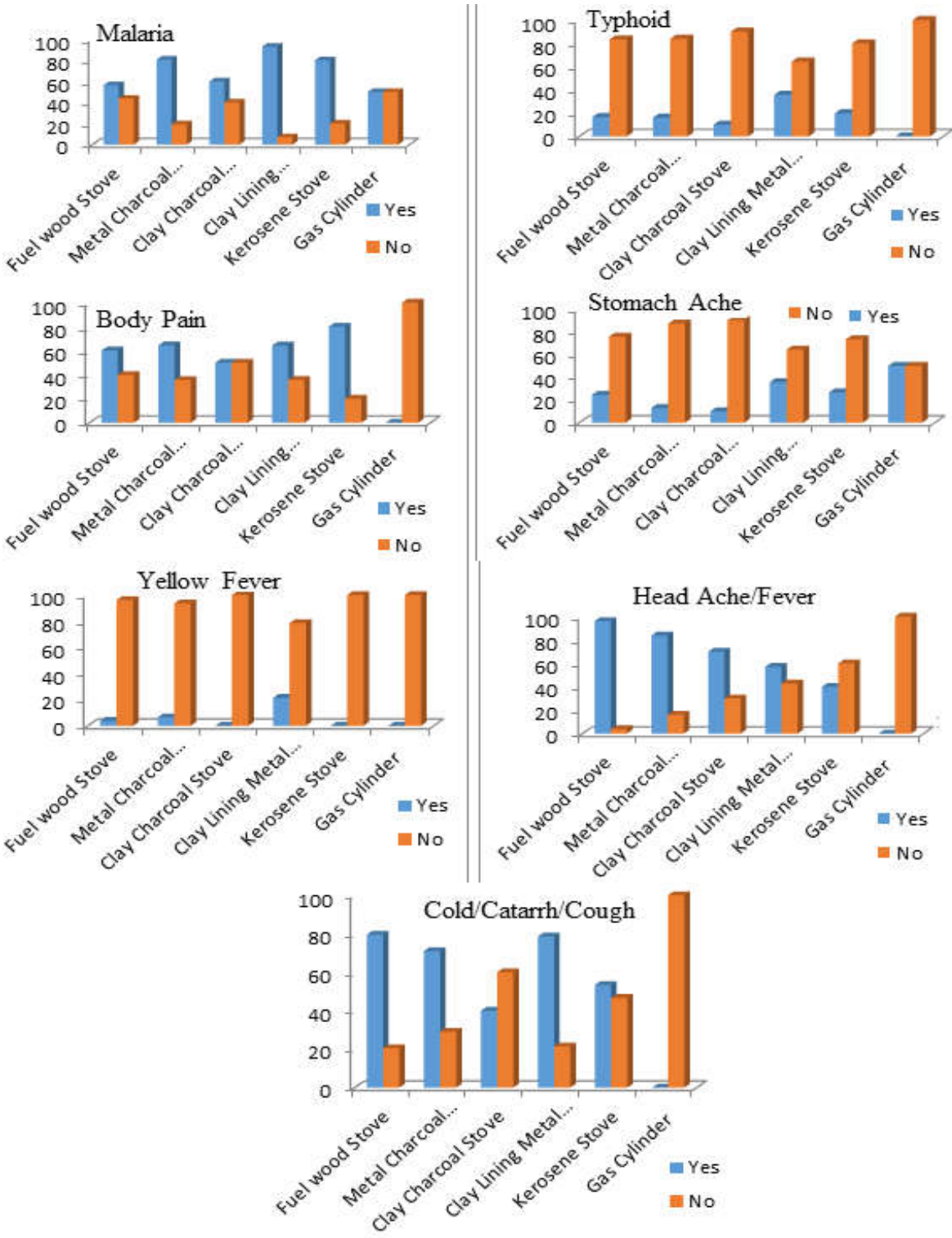

Fig 3a-4g: Histograms showing the percentage distributions of the cross tabulation of the ailments recently

Table 7: Stove and Type of Fuel used per meal with their respective prices with CO emission

\begin{tabular}{|c|c|c|c|c|c|}
\hline Stove Type & Fuel type & $\begin{array}{l}\text { Fuel quantity } \\
\text { /meal }\end{array}$ & $\begin{array}{l}\text { Price of } \\
\text { Stove ( })\end{array}$ & $\begin{array}{l}\text { Price of fuel } \\
\text { used ( })\end{array}$ & $\begin{array}{l}\text { Air quality } \\
\text { CO (ppm) }\end{array}$ \\
\hline Tripod stone fuel wood stove & Fuel wood & $4.30 \mathrm{~kg}$ & 0.00 & 59.34 & 98.25 \\
\hline Metal triple fuel wood stove & Fuel wood & $4.50 \mathrm{~kg}$ & 800 & 62.10 & 104.71 \\
\hline Metal charcoal Stove & Charcoal & $1.20 \mathrm{~kg}$ & 1500 & 63.00 & 84.53 \\
\hline Clay charcoal stove & Charcoal & $0.58 \mathrm{~kg}$ & 3000 & 38.33 & 22.56 \\
\hline $\begin{array}{l}\text { Clay lined metal charcoal } \\
\text { ctove }\end{array}$ & Charcoal & $0.73 \mathrm{~kg}$ & 5000 & 30.45 & 39.49 \\
\hline Kerosene stove & Kerosene & 0.34 liter & 2500 & 76.00 & 23.14 \\
\hline $6 \mathrm{~kg}$ Gas cylinder & LPG & $0.14 \mathrm{~kg}$ & 9500 & 74.96 & 5.44 \\
\hline
\end{tabular}

OLAOYE, IJ; AKINGBADE, AV; ALATISE, I 
Table 8: Indigenous Knowledge and Coping Strategies used in Managing Air Pollution as a Result of Cooking Stoves and Fuel Type Used

\begin{tabular}{lll}
\hline Managing/Coping strategies & Frequency & Percentage \\
\hline Opening of the window for thorough ventilation & 93 & 34.07 \\
Moving away from the kitchen environment & 64 & 23.44 \\
Re arrange the wood in the stove & 17 & 6.23 \\
fanning of the wood fuel stove to stimulate proper combustion & 30 & 10.99 \\
Quenching of wood producing smoke & 57 & 20.88 \\
Removal of the fuel wood producing smoke & 12 & 4.39 \\
\hline Total & 273 & 100.00 \\
\hline
\end{tabular}

Source: Field Survey Data 2016. * Open ended and Multiple Responses

Coping Strategies used to Manage Indoor Air Pollution by Rural Households: From observation and past experience, it could be noted that the indigenous people have their own local way of managing or coping with the issues related with indoor air pollution. Therefore, this study also focuses on the assessment of the indigenous knowledge and coping strategies used by the rural households in managing indoor air pollution. Table 8 shows the result of the indigenous knowledge and coping strategies used among rural households in managing and coping with air pollution as result of cooking stove and fuel used. It revealed that, the three most important practices used by the rural households in managing and coping with indoor air pollution were opening of the window for thorough ventilation (34.07\%), moving away from the kitchen environment (23.44\%) and quenching of the wood fuel producing smoke $(20.88 \%)$. The least used practices indulge by the rural households in managing and coping with air pollution were rearrange of the wood in the stove $(6.23 \%)$ and removal of the fuel wood producing smoke $(4.39 \%)$.

Conclusion: Owing to the use of biomass cooking stoves, the level of $\mathrm{CO}$ and $\mathrm{SO}_{2}$ concentrations in the kitchen were higher when compare with the WHO recommended exposure limit. The effects of indoor pollution due to the use of inefficient cooking stove on rural household health are eye irritation; skin irritation and head ache. Fever and respiratory infections such as head ache, cold, catarrh and cough are the most associated health problems with IAP from biomass combustion. However, the rural households in cope with indoor air pollution by ensuring thorough ventilation or moving far away from the kitchen during cooking. Thus, indoor cooking with the use of inefficient wood or charcoal stoves should be discouraged and governments should make policies that encourage the use of cleaner fuels among rural households.

Acknowledgment: The researchers are grateful to the Board of Pan African University and African Union for providing a sum of 2,000 USD grant for conducting this research work. Also, the researchers appreciate the contributions of Dr. (Mrs.) Abdulraheem of the Department Chemistry, University of Ilorin, Nigeria for the assistance given in the area of instrument procurement from United State which was used to monitor the air pollutants and for making her laboratory useful during the course of data collection. Finally, we appreciate the contribution of Professor Adenikinju Adeola and Professor Olatubara Charles O., to have supervised this research work.

\section{REFERENCE}

American Thoracic Society (2008). Forum of International Respiratory Societies Report. Biomass Fuels and Respiratory Diseases, A Review of the Evidence. American Thoracic Society, 5: 577-590. New York, NY.

Amolegbe, K B; Adewumi, M O (2013). Energy Consumption of Rural Farming Households in Kwara State, Nigeria; Presented at $4^{\text {th }}$ international conference of the African Association of Agricultural Economics, www.icaaae.org

Balakrishnan, K; Smith, R K; Sambandam, S; Ramaswamy, P; Mehta, S (2004). Exposure Assesment for respirable particulates associated with household fuel in rural districts of Andhra, Pradesh, India. J. of Exposure Analysis \& Environ Epidemiology, 14: 514-525.

Bjorn, L; Hutton, G; Khanna, N (2008). Copenhagen Consensus: Air Pollution Challenge Paper Global Crises, Global Solutions: Second Edition', edited by Bjørn Lomborg, Cambridge University Press.

Bruce, N L; Rehfuess, E; Mehta, S; Hutton, G; Smith, $K$ (1998). Indoor biofuel air pollution and respiratory health: the role of confounding factors among women in highland Guatemala. Int. J. of Epidemiology 27 (3): 454-458.

Bruce, N; Perez-Padilla, R; Albalak, R (2000). Indoor Air Pollution in Developing Countries: A Major Environmental and Public Health Challenge. Bulletin of the WHO 78 (9): 1078-1092.

Bruce, N; Rehfuess, E; Mehta, S; Hutton, G; Smith, K (2005). Indoor Air Pollution, in Disease Control 
Priorities in Developing Countries, Jamison D, Breman J, Measham

Desai, M; Mehta, S; Smith, K (2004). Indoor smoke from solid fuels - assessing the environmental burden of disease at national and local levels. Environmental Burden of Disease Series, No. 4. WHO.

Dherani, M; Pope, D; Mascarenhas, M; Smith, K R; Weber, M; Bruce, N (2008). Indoor Air Pollution from Unprocessed Solid Fuel Use and Pneumonia Risk in Children Aged Under Five Years. A Systematic review and meta-analysis. Bulletin of the World Health Organization, May 2008, 86.

Eldred, T T; Satoshi, N (2012). The Levels of Toxic Air Pollutants in Kitchens with Traditional Stoves in Rural Sierra Leone. J. of Environ. Protection 3 (10): 74-85.

Ezzati, M; Kammen, D M (2001a). Quantifying the effects of exposure to indoor air pollution from biomass combustion on acute respiratory infections in developing countries. Environ. Health Perspectives, 109 (5): 481-488.

Ezzati, M; Kammen, D M (2001b). An exposureresponse relationship for acute respiratory infections as a result of exposure to indoor air pollution from biomass combustion in Kenya. The Lancet, 358 (9282): 619-624.

IEA (2006). World Energy Outlook. Chapter 15, Energy for Cooking in the Developing World. IEA/OECD Paris, France.

IEA (2010). Energy Poverty: How to Make Modern energy Access universal? Special early excerpt of the World Energy Outlook 2010 for the 2010 UN MDG Review Summit.

International Energy Agency (2014). Africa energy outlook, a Focus on Energy Prospects in SubSaharan Africa. World Energy Outlook Special Report

Kjellstrom, T; Lodh, M; McMichael, T; Ranmuthugala, G; Shrestha, R; Kingsland, S (2006). Air and water pollution: burden and strategies for control, in Disease Control Priorities in Developing Countries, Jamison D, Breman J, Measham A, Alleyne G, Claeson M, Evans D, Jha P, Mills A and Musgrove P, Editors. Oxford University Press: New York.
Knight, C V; Cooper, K R; Alberti, R R; Ember, L R (1985). Indoor Air Quality Related to wood Heaters. In: Proceedings of IAQ '86 Managing Indoor Air for Health and Energy Conservation. American Society of Heating, Refrigerating and Air Conditioning Engineers, Atlanta. pp 430-447.

Kwara State Planning Commission, (2004). Kwara State Economic Empowerment and Development Strategy (Kwseeds) 2005-2007. KWARA State, Nigeria.

Larsen, B; Guy, H; Neha, K (2008). "The Challenge of Air Pollution" Copenhagen Consensus 2008 Challenge Paper.

Legros, G; Havet, I; Bruce, N; Bonjour, S (2009). Energy Access Situation in Developing Countries, A Review Focusing on the Least Developed Countries and Sub-Saharan Africa, United Nations Development Programme, World Health Organization. WHO Factsheet No 292, http://www.who.int/mediacentre/factsheets/fs292 len/print.html

Mac (2009). Indoor Air Pollution Create Problems for Rural Areas. http://www.lifeofearth.org

Masera, O R; Barbara, S; Kammen, D; Daniel, M (2000). From Linear Fuel Switching to Multiple Cooking Strategies: A Critique and Alternative to the Energy Ladder Model. World Dev., 28 (12): 2083-2103.

Mumford, J L et al. (1987). Lung cancer and indoor air pollution in Xuan Wei, China. Sci., 235 (4785): 217-220.

National Population Commission (2014). Nigeria Demographic and Health Survey 2013; Federal Republic of Nigeria Abuja, Nigeria

NBS (2010). Nigerian National Bureau of Statistics, Annual Abstract of Statistics (2010) Abuja, Nigeria

NPC (2006). Nigerian National Population Commission -Census Data

Oguntoke, O; Opeolu, B O; Babatunde, N (2010). Indoor Air Pollution and Health Risks among Rural Dwellers in Odeda Area, South-Western Nigeria. Ethiopian J. of Environ. Stud. \& Managt. 3 (2): 67-83

Olaoye, I. J., Bolaji M., and Oloyede, A. O. (2020). Adoption of innovation technology in the face of 
efficient energy use: A case of improved biomass stoves in Kwara State, Nigeria. Afr. J. of Sci., Tech., Inn. \& Dev., 1799301(Routledge, Taylor \& Francis Group). https://doi.org/10.1080/20421338.2020.1799301

Puzzolo, E; Stanistreet, D; Pope, D; Bruce, N; Rehfuess, E (2013). Factors influencing the largescale uptake by households of cleaner and more efficient household energy technologies. A systematic review, London: EPPI-Centre, Social Science Research Unit, Institute of Education, University of London.

Rehfuess, E; Mehta, S; Prüss-Üstün, A (2006). Assessing household solid fuel use - multiple implications for the millennium development goals. Environ. Health Perspectives. 114(3): p. 373-8.

Schlag, N; Zuzarte, F (2008). Market Barriers to Clean Cooking Fuels in Sub-Saharan Africa: A Review of Literature. Stockholm Environment Institute, Stockholm

Smith, K R (2009). Health impacts of household fuel wood use in developing countries, http://www.fao.org/docrep.

Smith, K R; Liu, Y (1993). Indoor air pollution in developing countries. In: Samet J, (ed). Epidemiology of lung cancer. Lung biology in health and disease. New York: Marcel Dekker.

Smith, K R; Samet, J; Romieu, I; Bruce, N (2000). Indoor Air Pollution in Developing Countries and Acute Lower Respiratory Infections in Children. Thorax, 55 (6), 518- 532.

Smith-Sivertsen, T et al. (2004). Reducing Indoor Air Pollution with a Randomized Intervention Design - A Presentation of the Stove Intervention Study in the Guatemalan Highlands. Norsk Epidemiologi, 14 (2): 137-143.

Stefan, T (2014). What users can save with energyefficient stoves and ovens. Wuppertal Institute for Climate, Environment and Energy. Wuppertal, Germany. http:// bigee.net
Traynor, G W; Hamilton, M; Marbury, M; Wanner, E U (1985). Indoor Air Pollution due to Emissions from wood-burning stoves. LBL-17854 Lawrence Berkeley Laboratory, Berkeley, C.A. pp 264-281.

UNDP (2009). The Energy Access in Situation in Developing Countries: A Review Focusing on the Least Developed Countries and Sub-Saharan Africa. UNDP, New York, NY.

WHO (2002). "The World Health Organization Report 2002 - Reducing Risks, Promoting Healthy Life. Geneva, World Health Organization". City.

WHO (2005). Air Quality Guidelines for Particulate Matter, Ozone, Nitrogen Dioxide and Sulfur Dioxide: Global Update 2005, World Health Organization, Geneva.

WHO (2006). Fuel for Life: Household Energy and Health, Geneva.

WHO (2008). Evaluating Household Energy and Health Interventions: A Catalogue of Methods. World Health Organization, Geneva, Switzerland.

WHO (2010). World Health Organization guidelines for indoor air quality: selected pollutants. WHO Regional Office for Europe coordinated the development of these WHO guidelines

World Bank (2007). World development indicators 2007. Washington D.C.

World Bank (2009). Environmental Crisis or Sustainable Development Opportunity, Transforming the Charcoal Sector in Tanzania. A Policy Note. The World Bank, Environment and Natural Resources Unit, Washington, DC. 